\title{
The intercellular metabolic interplay between tumor and immune cells
}

\author{
Tingting Wang ${ }^{1}$, Guangwei Liu ${ }^{2,3}$ and Ruoning Wang ${ }^{1,4,5 *}$ \\ ${ }^{1}$ Center for Childhood Cancer and Blood Disease, The Research Institute at Nationwide Children's Hospital, Columbus, OH, USA \\ ${ }^{2}$ Key Laboratory of Medical Molecular Virology of Ministries of Education and Health, Department of Immunology, School of Basic Medical Sciences, Fudan \\ University, Shanghai, China \\ ${ }^{3}$ Biotherapy Research Center, Fudan University, Shanghai, China \\ ${ }^{4}$ Hematology/Oncology \& BMT, The Research Institute at Nationwide Children's Hospital, Columbus, OH, USA \\ ${ }^{5}$ Department of Pediatrics, The Ohio State University School of Medicine, Columbus, OH, USA
}

Edited by:

Claudio Mauro, Queen Mary

University of London, UK

Reviewed by:

Christian Frezza, Hutchison/MRC

Research Institute, UK

Katiuscia Bianchi, Queen Mary

University of London, UK

\section{*Correspondence:}

Ruoning Wang, Center for Childhood

Cancer and Blood Disease, The

Research Institute at Nationwide

Children's Hospital, 700 Children's

Drive, Room WA5016, Columbus, $\mathrm{OH}$

43205, USA

e-mail: ruoning.wang@

nationwidechildrens.org
Functional and effective immune response requires a metabolic rewiring of immune cells to meet their energetic and anabolic demands. Beyond this, the availability of extracellular and intracellular metabolites may serve as metabolic signals interconnecting with cellular signaling events to influence cellular fate and immunological function. As such, tumor microenvironment represents a dramatic example of metabolic derangement, where the highly metabolic demanding tumor cells may compromise the function of some immune cells by competing nutrients (a form of intercellular competition), meanwhile may support the function of other immune cells by forming a metabolic symbiosis (a form of intercellular collaboration). It has been well known that tumor cells harness immune system through information exchanges that are largely attributed to soluble protein factors and intercelIular junctions. In this review, we will discuss recent advance on tumor metabolism and immune metabolism, as well as provide examples of metabolic communications between tumor cells and immune system, which may represent a novel mechanism of conveying tumor-immune privilege.

Keywords: metabolism, tumor, tumor immunity, antagonism, symbiosis

\section{INTERCELLULAR METABOLIC INTERACTION}

The intercellular communication largely relies on the information exchange via soluble factors (e.g., proteins and microRNAs) and direct cell-cell contacts. Beyond this, the shuttling of metabolites may serve as an additional form of intercellular communication and a high degree of intercellular coordination in various physiopathological situations. As an intensive energy-consuming organ, brain efficiently utilizes nutrients/metabolites via organizing a complex intercellular shuttle of glucose, glutamine, glutamate, pyruvate, and lactate between neurons and astrocytes (1). Similar metabolic coordination exists in retina between glial cells and photoreceptor cells, in muscle between fast white fibers and slow red fibers, and in testis between sertoli cells and spermatogenic cells (2, 3). Also, emerging evidences have shown that various pathogenderived metabolites mediate an intercellular host-pathogen interaction and critically impact on homeostasis and pathogenesis during pathogen invasion (4-7). Tumor microenvironment represents a dramatic example of metabolic derangement, where tumorsurrounding cells may either compromise or support highly metabolic demanding tumor cells by competing nutrients (a form of intercellular competition) or by forming a metabolic symbiosis (a form of intercellular collaboration), respectively. Amino acids, lactate, and lipids derived from stromal cells, adipocytes, mesenchymal stem cells, epithelial cells, or tumor cells from hypoxic regions can modulate tumor cell growth and their responses to therapy (8-15). Beyond this, the immune system, a pivotal cellular compartment presented in tumor microenvironment, is intimately involved in tumor initiation, progression, and responses to therapy.

\section{TUMOR IMMUNITY}

Interaction of immune system with tumor is a complex and dynamic process. As the major component of anti-tumor immunity, tumor antigen-specific cytotoxic $\mathrm{T}$ (CTL) and $\mathrm{T}$ effector $\left(\mathrm{T}_{\text {eff }}\right)$ cells together with antibody-producing B cells and antigenpresenting dendritic cells (DC) elicit adaptive anti-tumor activity through direct recognizing and killing tumor cells and orchestrating a plethora of adaptive and innate immune responses. Also, macrophages, natural killer (NK) cells, and NK-T cells form an important layer of non-specific innate immunity to suppress tumor progression. However, tumor often co-opts and manipulates its microenvironment favoring the development of immunosuppressive cells, such as myeloid-derived suppressor cells (MDSC) and regulatory $\mathrm{T}\left(\mathrm{T}_{\text {reg }}\right)$ cells. In addition, tumorassociated macrophages (TAMs), a pivotal immune population within the tumor microenvironment, are composed of multiple distinct pro- and anti-tumoral subpopulations. Mounting evidence indicates that strengthening the amplitude and quality of $\mathrm{T}$ cell-mediated adaptive response is one of the most promising approaches to enhance therapeutic anti-tumor immunity (16-19).

\section{METABOLIC REPROGRAMING IN TUMOR}

The shift from glucose oxidation toward aerobic glycolysis, also termed "Warburg effect," and heightened glutamine catabolism 
are characteristic hallmarks of cancer cells. The metabolic rewiring of cancer cells supporting tumor growth and survival relies on a hierarchical oncogenic cascade involved in Akt/mTOR, MAPK, and essential transcriptional factors, such as HIF $1 \alpha-$ and Mycdependent metabolic transcriptome. Secretion of metabolic end products, such as lactate from glycolysis and glutaminolysis and $\mathrm{CO}_{2}$ from the pentose phosphate pathway, often result in an extracellular acidification in tumor microenvironment. Hence, the $\mathrm{Na}^{+} / \mathrm{H}^{+}$exchanger, the $\mathrm{H}^{+}$-lactate co-transporter, monocarboxylate transporters, and the proton pump $\left(\mathrm{H}^{+}\right.$-ATPase $)$that are frequently activated in cancer cells play essential role in modulating the $\mathrm{pH}$ and ionic compositions in tumor microenvironment (20-22). Also, elevated expression of phosphoglycerate dehydrogenase (PHGDH) and it-mediated diversion of glycolysis into serine biosynthetic pathway have been found to be essential for the proliferation of certain tumor cells, such as breast cancer cells and melanoma cells $(23,24)$. Beyond being key precursors for biosynthesis, metabolic products of tryptophan, cysteine, serine, and glycine also contribute to tumor homeostasis through modulating anti-oxidative response and anti-tumor immunity $(8,25-28)$. Together, the metabolic reprograming in tumor contributes to its growth either by directly supporting cancer cell proliferation or by shaping the microenvironment potentially favoring tumor cell survival.

\section{METABOLIC REPROGRAMING IN IMMUNE SYSTEM}

Recent studies from us and others have indicated that metabolic regulation and cell signaling are tightly and ubiquitously linked with immune responses (29-34). The distinct metabolic profiles of lymphocytes are intimately linked to their status and function (Table 1). Naïve T lymphocytes rely mainly on fatty acid oxidation and some glycolysis to fulfill their energy demand for survival. Upon stimulation, activated T lymphocyte "reprograms" its metabolism, by dramatically increasing aerobic glycolysis and glutaminolysis meanwhile decreasing lipid oxidation to meet its requirements for cell size growth, cell division, and cytokine production (35-38). In contrast, stimulation of B lymphocytes leads to a balanced increase in aerobic glycolysis and oxygen consumption $(39,40)$. As T lymphocytes begin to proliferate, they also undergo differentiation into functional subsets in response to extracellular signals, and these subsets determine the nature of the immune response. According to the nature of initial antigen challenge and specific cytokine signals, activated CD4 T cells differentiate into $\mathrm{T}_{\text {eff }}$, including $\mathrm{T}$ helper Th1, Th2, Th9, and Th17, follicular helper $\mathrm{Tfh}$, and $\mathrm{T}_{\text {reg. }}$. Th1 cells mediate responses to intracellular pathogens. Th2 cells control responses to extracellular bacteria and helminthes. Th9 cells play a role in the pathogenesis of asthma and resolution of parasitic infections. Th17 cells are important in anti-fungal defense and inflammation. Tfh cells are the specialized $\mathrm{B}$ cell helper. $\mathrm{T}_{\text {reg }}$ cells dampen immune responses by suppressing $\mathrm{T}$ cell activation and inflammatory response. The predominant metabolic program in $\mathrm{T}_{\text {reg }}$ cells is mitochondrial-dependent oxidation of lipid and potentially other mitochondrial-dependent metabolites. It has been indicated that forcing proliferating $\mathrm{T}$ cells to utilize free fatty acids for energy tends to drive enhanced $\mathrm{T}_{\text {reg }}$ differentiation (41). In contrast, increased aerobic glycolysis is seen in Th1, Th2, and Th17 cells, and partially due to activation of PI3K/Akt/mTOR pathway. The transcription factor HIF1 (hypoxia-inducible factor 1) has also been characterized as a key regulator of the anabolic metabolism in differentiating Th17 cells $(42,43)$. Similar to CD4 T cells, CD8 T cells also switch from fatty acid oxidation to aerobic glycolysis upon activation. The glycolysis and anabolic metabolism are essential for CD8 T cell growth and differentiation into cytotoxic $\mathrm{T}$ cells (34). After the peak of the primary $\mathrm{T}$ cell response, the metabolic state in CD8 T cells shifts from glycolysis back to lipid oxidation, which is pivotal for cell survival and the generation of CD8 T memory cells $(44,45)$.

Dendritic cells and macrophages are first-line effectors of innate immunity. DC maturation is concomitant with a metabolic switch to aerobic glycolysis $(46,47)$. Aerobic glycolysis fulfills bioenergetic need and also provides building blocks for the biosynthesis of macromolecules, such as lipids, a proper balance between uptake and synthesis of which is required for immunogenicity of DCs $(48,49)$. As functionally plastic cells, macrophages are capable of tightly coordinating their metabolic programs with their functional properties. This allows macrophages to grow, survive, and properly respond to a variety of pathophysiological signals in their changing microenvironments. Within the tumor microenvironment, TAMs are often identified as protumoral M2 type macrophage $(50,51)$. Mounting evidences have showed that switching the TAM phenotype from M2 to M1 may promote anti-tumor activity, implicating a phenotypic plasticity of TAM (52-57). To mount a rapid inflammatory response, M1 macrophages coordinately engage aerobic glycolysis, pentose phosphate shunt (PPP), glutamine, and arginine catabolism to produce nitric oxide (NO) and reactive oxygen species (ROS) (58-60). However, anti-inflammatory M2 macrophages largely utilize lipid oxidation (61-63) meanwhile shift arginine catabolism from iNOS-mediated production of NO to the production of urea and ornithine (64-68). Similar to macrophage, the polarization of MDSC, a heterogeneous immunosuppressive population in tumor microenvironment, toward a pro-inflammatory phenotype (often referred as M1) is associated with heightened glycolysis meanwhile reduced immunosuppressive function (69). Beyond this, metabolic regulation in NK and neutrophils are largely unknown.

Table 1 | Metabolic profiles of immune cells.

\begin{tabular}{|c|c|c|c|c|c|c|c|}
\hline $\begin{array}{l}\text { Immune } \\
\text { cells }\end{array}$ & Naïve T cells & Activated T cells & $\mathbf{T}_{\text {eff }}$ cells & $\begin{array}{l}\mathrm{T}_{\text {reg }} / \mathrm{T} \text { memory } \\
\text { cells }\end{array}$ & $\begin{array}{l}\text { Activated } \\
\text { dendritic cells }\end{array}$ & M1 macrophages & $\begin{array}{l}\text { M2 macrophage } \\
\text { (TAM) }\end{array}$ \\
\hline $\begin{array}{l}\text { Metabolic } \\
\text { profile }\end{array}$ & $\begin{array}{l}\text { fatty acid } \\
\text { oxidation and } \\
\text { some glycolysis }\end{array}$ & $\begin{array}{l}\text { Glycolysis and } \\
\text { glutaminolysis }\end{array}$ & Glycolysis & $\begin{array}{l}\text { Fatty acid } \\
\text { oxidation }\end{array}$ & Glycolysis & $\begin{array}{l}\text { Glycolysis, pentose phosphate } \\
\text { shunt (PPP), glutamine, and } \\
\text { arginine catabolism }\end{array}$ & Lipid oxidation \\
\hline
\end{tabular}




\section{METABOLIC ANTAGONISM AND SYMBIOSIS IN TUMOR MICROENVIRONIMENT}

Aerobic glycolysis and glutaminolysis are dominant cancer metabolic routes. Heightened glucose and glutamine consumption often results in the depletion of nutrients (glucose, glutamine, etc.) whereas accumulates metabolic end- or by-products (lactate, proton, etc.) in tumor microenvironment $(70,71)$. In addition to the above general metabolic features that are required to support the needs of proliferation and other neoplastic features, tumor cells also exhibit diverse metabolic phenotypes that are often due to the adaptation of pre-existing cell/tissue lineage specific metabolic network. It is well documented that in tumor cells, biosynthesis, and catabolism of glycine and serine, as well as catabolism of tryptophan and cysteine, are essential to support tumor cell survival $(25,72-74)$. Acidic extracellular $\mathrm{pH}$, which is resulted from the accumulation of lactate and $\mathrm{CO}_{2}$ production, has been demonstrated to be important for cancer progression $(75,76)$. Recent studies have demonstrated that anti-tumoral immune population, such as CTL and $\mathrm{T}_{\text {eff }}$ cells, engage robust aerobic glycolysis and glutaminolysis, suggesting a potential metabolic antagonism (competition) for nutrients between tumor and those immune cells. On the contrary, pro-tumoral immune suppressive cells may preferentially utilize metabolic products of tumor to form a potential metabolic symbiosis in tumor microenvironment (Figure 1).

\section{ANTAGONISM}

\section{Glucose and glutamine}

The similarity of metabolic programs between tumor and $\mathrm{T}$ cells (CTL and $\mathrm{T}_{\text {eff }}$ ) leads to fierce competition for limited source of glucose and glutamine in local environment. The restriction of glucose and glutamine to fast proliferating cells could result in metabolic stress on both tumor and immune cells. Nutrient deprivation elicits signaling responses through AMP-dependent kinase (AMPK), mammalian target of rapamycin (mTOR), transcriptional factor p53, and other unknown signaling modulators to confer metabolic plasticity allowing cancer cells survive under low glucose and low glutamine condition (77-81). Furthermore, lactate and $\mathrm{CO}_{2}$ produced from glycolysis and glutaminolysis lead to microenvironment acidification, favoring the development of more aggressive and invasive tumor cells $(75,76)$. Unlike tumor cells, metabolic stresses are less tolerated in non-malignant cells, such as $\mathrm{T}$ cells, and are often immune suppressive, partially due to a preferential development of $T_{\text {reg }}$ cells following nutrients restriction $(41,42)$. Several studies also indicated that nutrient starvation perturbs $\mathrm{T}_{\text {eff }}$ cytokine production, macrophage phagocytic activity, and superoxide production. Therefore, metabolic microenvironment may render tumor cells a selective advantage due to their resistance to apoptosis and rapid adaptation under metabolic stress.

\section{Tryptophan catabolism}

The catabolism of the essential amino acid tryptophan has been reported to be a biomarker of tumor tissues in various studies. In tumor cells, the conversion of tryptophan to kynurenine is primary mediated by two dioxygenases, indoleamine-2,3dioxygenase (IDO) and tryptophan-2,3-dioxygenase (TDO). IDO is expressed in many types of tumor cells and antigen-presenting

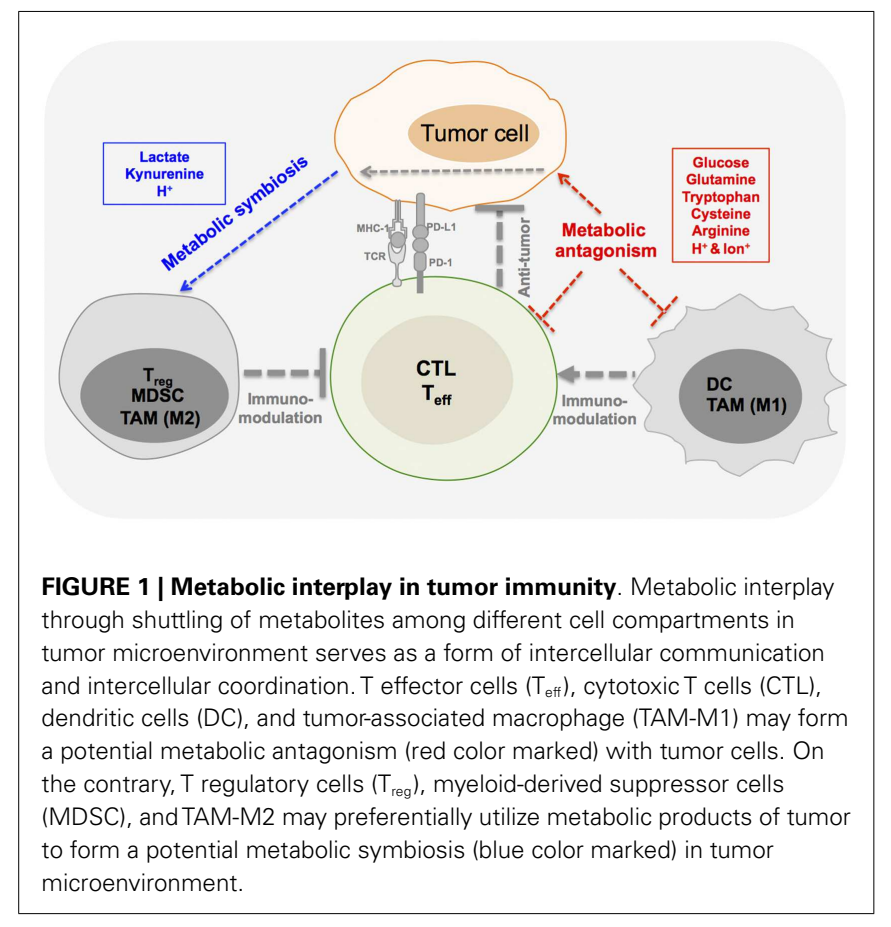

cells, whereas TDO exists in certain IDO-negative tumor cells, such as malignant gliomas and hepatocellular carcinoma (82-85). The breakdown of tryptophan has been shown to dramatically affect the function of $\mathrm{T}$ cells against tumor cells. On one hand, upregulated tryptophan catabolism in tumor tissue resulted in the depletion of tryptophan in the extracellular space, which causes $\mathrm{T}_{\text {eff }}$ cells anergy and apoptosis and, in turn, suppresses anti-tumor-immune responses. On the other hand, kynurenine and potentially other catabolic metabolites of tryptophan are nature ligands of aryl hydrocarbon receptor (AHR), which plays a broad role in modulating immunity $(86,87)$. As such, extracellular accumulation of kynurenine elicits an AHR-mediated response to reciprocally enhance function of $T_{\text {reg }}$ and suppress function of $\mathrm{T}_{\text {eff }}$ and immunogenicity of DCs (88-90). Thus, tryptophan depletion and kynurenine accumulation cooperatively create an immunosuppressive microenvironment in tumor $(25,90)$.

\section{Cysteine and glycine}

Physiological levels of ROS play essential roles in various signaling cascades for cell survival and proliferation, whereas excess ROS causes cell injury and tissue damage $(91,92)$. The thiol group in glutathione (GSH) acts as a reducing agent that can quench the cytotoxic ROS, and thus GSH is considered as an essential cellular antioxidant system to maintain redox homeostasis. Heightened GSH level is observed in numerous types of cancers, and the enriched GSH improves tumor cell survival by protecting them against oxidative stress $(73,74)$. Tumor cells uptake cysteine and cystine from the local environment and convert them into GSH together with glutamate and glycine, which are often derived from glutamine and glucose. Similarly, $\mathrm{T}$ cell proliferation depends on the uptake of exogenous cysteine. T cells lack cystathionase enzyme that converts methionine to cysteine and xc-transporter that imports cystine as an alternative source of 
cysteine (93). Thus, the competition between tumor cells and $\mathrm{T}$ cells for cysteine and glycine may lead to the suppression of $\mathrm{T}$ cell activation and proliferation.

\section{Arginine catabolism}

As another form of free radical, NO plays multifaceted roles in cancer initiation, progression, differentiation, and angiogenesis (94-96). In mammals, NO is converted by a family of nitric oxide synthases (NOS) from arginine. It has been reported that arginine depletion retards the growth of some types of tumor, whereas other studies demonstrated that arginine supplementation assists anti-tumor treatment possibly by enhancing immune function $(97,98)$. As such, arginine has been discovered to stimulate T cell and NK cell activity and promote production of pro-inflammatory cytokines $(99,100)$. Also, tumor-derived NO may elicit cytotoxic effects on tumor-associated immune cells. However, the intrinsic resistance to $\mathrm{NO}$-mediated cytotoxicity of tumor cells with mutated p53 offers a selective growth advantage of cancer cells over normal cells (101-104).

\section{Proton and sodium ion}

It has been known that the acidification of microenvironment caused by the accumulation of lactic acid and $\mathrm{CO}_{2}$ enhances tumor radioresistance and favors tumor cell migration and invasion (75, $76,105)$. Beyond this, acidic environment decreases the activity of NK cells, suppresses T cell proliferation, and impairs cytokine production and cytotoxic activity of T cells. Accumulating evidences also suggest that acidic microenvironment has a profound impact on monocytes differentiation and cytokine release (106-108). As one of the key inorganic ions in our body, cross-membrane transport of sodium ion is intimately coupled with proton and amino acids transport and also profoundly impact on tumor microenvironment $(75,109)$. Recent studies show that high-sodium chloride conditions induce the development of pathogenic Th17 cells with elevated release of pro-inflammatory cytokines (GM-CSF, TNF- $\alpha$, and IL-2) and thus promote tissue inflammation, which may either promote or suppress tumor formation. While some of the effects of sodium are mediated through serum/glucocorticoid-regulated kinase 1 (SGK1), further investigations are warranted to assess the impact of sodium on proton and amino acids transport. As such, a sodium ion-proton axis may coordinately modulate anti-tumor response $(110,111)$.

\section{METABOLIC SYMBIOSIS}

In contrast to $\mathrm{T}_{\text {eff }}$ cells, the enriched lactate and the acidic microenvironment do not have obviously suppressive effect on $\mathrm{T}_{\text {reg }}$ cells, as they have a different energy metabolism that relies on fatty acid oxidation. The lactate accumulated in the microenvironment is generally considered as metabolic "waste." However, numerous studies have indicated the possible function of lactate as a prominent substrate in oxidative metabolism among various types of cells such as muscle cells, neurons, and certain tumor cells (112114). Although, it has not been demonstrated, the preference of mitochondrial-dependent oxidative metabolism of $\mathrm{T}_{\text {reg }}$ indicates the possibility that $\mathrm{T}_{\text {reg }}$ may utilize lactate under nutrient scarcity, which often happens in tumor microenvironment. The concentration of lactate in vertebrate plasma ranges from 1 to $30 \mathrm{mM}$ under physiological and pathological conditions (2). Beyond serving as a potential alternative energy source, early studies suggested that high lactate concentrations $(2-30 \mathrm{mM})$ enhance $\mathrm{T}_{\text {reg }}$ differentiation through the stimulation of IL-2 production $(115,116)$. Similarly, increased production of lactate by tumor cells promotes the development of MDSC (117). Also, lactate and acidic environment have a profound impact on secretory profile of TAM, promoting tumor angiogenesis $(108,118,119)$. Beyond lactate, the catabolic metabolites of tryptophan, such as kynurenine, promote $\mathrm{T}_{\text {reg }}$ differentiation and immune suppressive function (89). Thus, tumor-derived lactate and tryptophan catabolic metabolites may form a layer of metabolic symbiosis with various immune cells to favor tumor growth.

\section{CONCLUSION AND PERSPECTIVE}

The metabolites that present in tumor microenvironment may also have signaling functions independent of their roles of bioenergetics fuels. This may represent a general feature of the intercellular metabolic crosstalk mediated by metabolites. To fully understand the underlying complexity of intercellular metabolic interplay, new techniques that allow us to quantitative measure metabolites, assess metabolic flux in situ, and detect physical interaction between metabolites and cell surface proteins are warranted. The fast moving cancer metabolism field and immunotherapy field have generated tremendous excitement regarding new therapeutic strategies and will likely change the paradigm of therapeutic interventions for cancer. However, the perturbed metabolic landscape of the tumor microenvironment can have a profound impact on anti-tumor immunity. As such, understanding the metabolic interplay between tumor and immune system will guide the development of optimal metabolic interventions on cancer without compromising anti-tumor immunity. Beyond this, intercellular metabolic interplay may also play an essential role in forming a pro-tumoral inflammatory microenvironment.

\section{ACKNOWLEDGMENTS}

This work was supported by the American Cancer Society Institutional Research Seed Grant and Elsa U. Pardee Foundation Research Grant (Ruoning Wang).

\section{REFERENCES}

1. Belanger M, Allaman I, Magistretti PJ. Brain energy metabolism: focus on astrocyte-neuron metabolic cooperation. Cell Metab (2011) 14(6):724-38. doi:10.1016/j.cmet.2011.08.016

2. Merezhinskaya N, Fishbein WN. Monocarboxylate transporters: past, present, and future. Histol Histopathol (2009) 24(2):243-64.

3. Brooks GA. Cell-cell and intracellular lactate shuttles. J Physiol (2009) 587(Pt 23):5591-600. doi:10.1113/jphysiol.2009.178350

4. Lee KA, Kim SH, Kim EK, Ha EM, You H, Kim B, et al. Bacterial-derived uracil as a modulator of mucosal immunity and gut-microbe homeostasis in Drosophila. Cell (2013) 153(4):797-811. doi:10.1016/j.cell.2013.04.009

5. Baruch M, Belotserkovsky I, Hertzog BB, Ravins M, Dov E, McIver KS, et al. An extracellular bacterial pathogen modulates host metabolism to regulate its own sensing and proliferation. Cell (2014) 156(1-2):97-108. doi:10.1016/j.cell. 2013.12.007

6. Donohoe DR, Garge N, Zhang X, Sun W, O'Connell TM, Bunger MK, et al. The microbiome and butyrate regulate energy metabolism and autophagy in the mammalian colon. Cell Metab (2011) 13(5):517-26. doi:10.1016/j.cmet.2011. 02.018 
7. Wang Z, Klipfell E, Bennett BJ, Koeth R, Levison BS, Dugar B, et al. Gut flora metabolism of phosphatidylcholine promotes cardiovascular disease. Nature (2011) 472(7341):57-63. doi:10.1038/nature09922

8. Zhang W, Trachootham D, Liu J, Chen G, Pelicano H, Garcia-Prieto C, et al. Stromal control of cystine metabolism promotes cancer cell survival in chronic lymphocytic leukaemia. Nat Cell Biol (2012) 14(3):276-86. doi:10. $1038 /$ ncb 2432

9. Pavlides S, Whitaker-Menezes D, Castello-Cros R, Flomenberg N, Witkiewicz AK, Frank PG, et al. The reverse Warburg effect: aerobic glycolysis in cancer associated fibroblasts and the tumor stroma. Cell Cycle (2009) 8(23):3984-4001. doi:10.4161/cc.8.23.10238

10. Das SK, Eder S, Schauer S, Diwoky C, Temmel H, Guertl B, et al. Adipose triglyceride lipase contributes to cancer-associated cachexia. Science (2011) 333(6039):233-8. doi:10.1126/science.1198973

11. Kung HN, Marks JR, Chi JT. Glutamine synthetase is a genetic determinant of cell type-specific glutamine independence in breast epithelia. PLoS Genet (2011) 7(8):e1002229. doi:10.1371/journal.pgen.1002229

12. Roodhart JM, Daenen LG, Stigter EC, Prins HJ, Gerrits J, Houthuijzen JM, et al. Mesenchymal stem cells induce resistance to chemotherapy through the release of platinum-induced fatty acids. Cancer Cell (2011) 20(3):370-83. doi:10.1016/j.ccr.2011.08.010

13. Nieman KM, Kenny HA, Penicka CV, Ladanyi A, Buell-Gutbrod R, Zillhardt $\mathrm{MR}$, et al. Adipocytes promote ovarian cancer metastasis and provide energy for rapid tumor growth. Nat Med (2011) 17(11):1498-503. doi:10.1038/nm.2492

14. Fiaschi T, Marini A, Giannoni E, Taddei ML, Gandellini P, De Donatis A, et al. Reciprocal metabolic reprogramming through lactate shuttle coordinately influences tumor-stroma interplay. Cancer Res (2012) 72(19):5130-40. doi:10.1158/0008-5472.can-12-1949

15. Sonveaux P, Vegran F, Schroeder T, Wergin MC, Verrax J, Rabbani ZN, et al. Targeting lactate-fueled respiration selectively kills hypoxic tumor cells in mice. J Clin Invest (2008) 118(12):3930-42. doi:10.1172/jci36843

16. June $\mathrm{CH}$. Adoptive $\mathrm{T}$ cell therapy for cancer in the clinic. J Clin Invest (2007) 117(6):1466-76. doi:10.1172/jci32446

17. June CH. Principles of adoptive T cell cancer therapy. J Clin Invest (2007) 117(5):1204-12. doi:10.1172/jci31446

18. Leen AM, Rooney CM, Foster AE. Improving T cell therapy for cancer. Annu Rev Immunol (2007) 25:243-65. doi:10.1146/annurev.immunol.25.022106.141527

19. Kershaw MH, Westwood JA, Darcy PK. Gene-engineered T cells for cancer therapy. Nat Rev Cancer (2013) 13(8):525-41. doi:10.1038/nrc3565

20. Cardone RA, Casavola V, Reshkin SJ. The role of disturbed $\mathrm{pH}$ dynamics and the $\mathrm{Na}+/ \mathrm{H}+$ exchanger in metastasis. Nat Rev Cancer (2005) 5(10):786-95. doi: $10.1038 / \mathrm{nrc17} 13$

21. De Milito A, Fais S. Tumor acidity, chemoresistance and proton pump inhibitors. Future Oncol (2005) 1(6):779-86. doi:10.2217/14796694.1.6.779

22. Kato Y, Ozawa S, Miyamoto C, Maehata Y, Suzuki A, Maeda T, et al. Acidic extracellular microenvironment and cancer. Cancer Cell Int (2013) 13(1):89. doi:10.1186/1475-2867-13-89

23. Possemato R, Marks KM, Shaul YD, Pacold ME, Kim D, Birsoy K, et al. Functional genomics reveal that the serine synthesis pathway is essential in breast cancer. Nature (2011) 476(7360):346-50. doi:10.1038/nature10350

24. Locasale JW, Grassian AR, Melman T, Lyssiotis CA, Mattaini KR, Bass AJ, et al. Phosphoglycerate dehydrogenase diverts glycolytic flux and contributes to oncogenesis. Nat Genet (2011) 43(9):869-74. doi:10.1038/ng.890

25. Platten M, Wick W, Van den Eynde BJ. Tryptophan catabolism in cancer: beyond IDO and tryptophan depletion. Cancer Res (2012) 72(21):5435-40. doi:10.1158/0008-5472.can-12-0569

26. Platten MW, Weller M, Wick W. Shaping the glioma immune microenvironment through tryptophan metabolism. CNS Oncol (2012) 1:99-106. doi:10.2217/cns.12.6

27. Tedeschi PM, Markert EK, Gounder M, Lin H, Dvorzhinski D, Dolfi SC, et al. Contribution of serine, folate and glycine metabolism to the ATP, NADPH and purine requirements of cancer cells. Cell Death Dis (2013) 4:e877. doi:10.1038/cddis.2013.393

28. Locasale JW. Serine, glycine and one-carbon units: cancer metabolism in full circle. Nat Rev Cancer (2013) 13(8):572-83. doi:10.1038/nrc3557

29. Wang R, Green DR. The immune diet: meeting the metabolic demands of lymphocyte activation. F1000 Biol Rep (2012) 4:9. doi:10.3410/B4-9
30. Wang R, Green DR. Metabolic reprogramming and metabolic dependency in T cells. Immunol Rev (2012) 249(1):14-26. doi:10.1111/j.1600-065X.2012. 01155.x

31. Maciver NJ, Jacobs SR, Wieman HL, Wofford JA, Coloff JL, Rathmell JC. Glucose metabolism in lymphocytes is a regulated process with significant effects on immune cell function and survival. J Leukoc Biol (2008) 84(4):949-57. doi:10.1189/jlb.0108024

32. Jones RG, Thompson CB. Revving the engine: signal transduction fuels $\mathrm{T}$ cell activation. Immunity (2007) 27(2):173-8. doi:10.1016/j.immuni.2007.07.008

33. Pearce EL, Pearce EJ. Metabolic pathways in immune cell activation and quiescence. Immunity (2013) 38(4):633-43. doi:10.1016/j.immuni.2013.04.005

34. Finlay D, Cantrell DA. Metabolism, migration and memory in cytotoxic T cells. Nat Rev Immunol (2011) 11(2):109-17. doi:10.1038/nri2888

35. Wang R, Dillon CP, Shi LZ, Milasta S, Carter R, Finkelstein D, et al. The transcription factor Myc controls metabolic reprogramming upon T lymphocyte activation. Immunity (2011) 35(6):871-82. doi:10.1016/j.immuni.2011.09.021

36. Jacobs SR, Herman CE, Maciver NJ, Wofford JA, Wieman HL, Hammen JJ, et al. Glucose uptake is limiting in T cell activation and requires CD28-mediated Akt-dependent and independent pathways. J Immunol (2008) 180(7):4476-86. doi:10.4049/jimmunol.180.7.4476

37. Frauwirth KA, Riley JL, Harris MH, Parry RV, Rathmell JC, Plas DR, et al. The CD28 signaling pathway regulates glucose metabolism. Immunity (2002) 16(6):769-77. doi:10.1016/S1074-7613(02)00323-0

38. Fox CJ, Hammerman PS, Thompson CB. Fuel feeds function: energy metabolism and the T-cell response. Nat Rev Immunol (2005) 5(11):844-52. doi:10. 1038/nril710

39. Caro-Maldonado A, Wang R, Nichols AG, Kuraoka M, Milasta S, Sun LD, et al. Metabolic reprogramming is required for antibody production that is suppressed in anergic but exaggerated in chronically BAFF-exposed B cells. J Immunol (2014) 192(8):3626-36. doi:10.4049/jimmunol.1302062

40. Doughty CA, Bleiman BF, Wagner DJ, Dufort FJ, Mataraza JM, Roberts MF et al. Antigen receptor-mediated changes in glucose metabolism in B lymphocytes: role of phosphatidylinositol 3-kinase signaling in the glycolytic control of growth. Blood (2006) 107(11):4458-65. doi:10.1182/blood-200512- 4788

41. Michalek RD, Gerriets VA, Jacobs SR, Macintyre AN, MacIver NJ, Mason EF, et al. Cutting edge: distinct glycolytic and lipid oxidative metabolic programs are essential for effector and regulatory CD4+ T cell subsets. J Immunol (2011) 186(6):3299-303. doi:10.4049/jimmunol.1003613

42. Shi LZ, Wang R, Huang G, Vogel P, Neale G, Green DR, et al. HIFlalphadependent glycolytic pathway orchestrates a metabolic checkpoint for the differentiation of TH17 and Treg cells. J Exp Med (2011) 208(7):1367-76. doi:10.1084/jem.20110278

43. Dang EV, Barbi J, Yang HY, Jinasena D, Yu H, Zheng Y, et al. Control of $\mathrm{T}(\mathrm{H}) 17 / \mathrm{T}(\mathrm{reg})$ balance by hypoxia-inducible factor 1. Cell (2011) 146(5):772-84. doi:10.1016/j.cell.2011.07.033

44. Sukumar M, Liu J, Ji Y, Subramanian M, Crompton JG, Yu Z, et al. Inhibiting glycolytic metabolism enhances CD8+ T cell memory and antitumor function. J Clin Invest (2013) 123(10):4479-88. doi:10.1172/jci69589

45. van der Windt GJ, Pearce EL. Metabolic switching and fuel choice during T-cell differentiation and memory development. Immunol Rev (2012) 249(1):27-42. doi:10.1111/j.1600-065X.2012.01150.x

46. Pantel A, Teixeira A, Haddad E, Wood EG, Steinman RM, Longhi MP. Direct type I IFN but not MDA5/TLR3 activation of dendritic cells is required for maturation and metabolic shift to glycolysis after poly IC stimulation. PLoS Biol (2014) 12(1):e1001759. doi:10.1371/journal.pbio.1001759

47. Krawczyk CM, Holowka T, Sun J, Blagih J, Amiel E, DeBerardinis RJ, et al. Tolllike receptor-induced changes in glycolytic metabolism regulate dendritic cell activation. Blood (2010) 115(23):4742-9. doi:10.1182/blood-2009-10-249540

48. Herber DL, Cao W, Nefedova Y, Novitskiy SV, Nagaraj S, Tyurin VA, et al. Lipid accumulation and dendritic cell dysfunction in cancer. Nat Med (2010) 16(8):880-6. doi:10.1038/nm.2172

49. Rehman A, Hemmert KC, Ochi A, Jamal M, Henning JR, Barilla R, et al. Role of fatty-acid synthesis in dendritic cell generation and function. J Immunol (2013) 190(9):4640-9. doi:10.4049/jimmunol.1202312

50. Mantovani A. Cancer: inflammation by remote control. Nature (2005) 435(7043):752-3. doi:10.1038/435752a 
51. Pollard JW. Tumour-educated macrophages promote tumour progression and metastasis. Nat Rev Cancer (2004) 4(1):71-8. doi:10.1038/nrc1256

52. Sica A, Schioppa T, Mantovani A, Allavena P. Tumour-associated macrophages are a distinct M2 polarised population promoting tumour progression: potential targets of anti-cancer therapy. Eur J Cancer (2006) 42(6):717-27. doi:10.1016/j.ejca.2006.01.003

53. Sessa C, De Braud F, Perotti A, Bauer J, Curigliano G, Noberasco C, et al. Trabectedin for women with ovarian carcinoma after treatment with platinum and taxanes fails. J Clin Oncol (2005) 23(9):1867-74. doi:10.1200/jco.2005.09.032

54. Wahl LM, Kleinman HK. Tumor-associated macrophages as targets for cancer therapy. J Natl Cancer Inst (1998) 90(21):1583-4. doi:10.1093/jnci/90.21.1583

55. Giraudo E, Inoue M, Hanahan D. An amino-bisphosphonate targets MMP9-expressing macrophages and angiogenesis to impair cervical carcinogenesis. J Clin Invest (2004) 114(5):623-33. doi:10.1172/jci22087

56. Guiducci C, Vicari AP, Sangaletti S, Trinchieri G, Colombo MP. Redirecting in vivo elicited tumor infiltrating macrophages and dendritic cells towards tumor rejection. Cancer Res (2005) 65(8):3437-46. doi:10.1158/0008-5472. can-04-4262

57. Franklin RA, Liao W, Sarkar A, Kim MV, Bivona MR, Liu K, et al. The cellular and molecular origin of tumor-associated macrophages. Science (2014) 344(6186):921-5. doi:10.1126/science. 1252510

58. Tannahill GM, Curtis AM, Adamik J, Palsson-McDermott EM, McGettrick AF, Goel G, et al. Succinate is an inflammatory signal that induces IL-1beta through HIF-1alpha. Nature (2013) 496(7444):238-42. doi:10.1038/nature11986

59. Stubbs M, Kuhner AV, Glass EA, David JR, Karnovsky ML. Metabolic and functional studies on activated mouse macrophages. J Exp Med (1973) 137(2):537-42. doi:10.1084/jem.137.2.537

60. Newsholme P, Costa Rosa LF, Newsholme EA, Curi R. The importance of fuel metabolism to macrophage function. Cell Biochem Funct (1996) 14(1):1-10. doi:10.1002/cbf.644

61. Vats D, Mukundan L, Odegaard JI, Zhang L, Smith KL, Morel CR, et al. Oxidative metabolism and PGC-1beta attenuate macrophage-mediated inflammation. Cell Metab (2006) 4(1):13-24. doi:10.1016/j.cmet.2006.05.011

62. Lacy-Hulbert A, Moore KJ. Designer macrophages: oxidative metabolism fuels inflammation repair. Cell Metab (2006) 4(1):7-8. doi:10.1016/j.cmet. 2006.06.001

63. Johnson AR, Milner JJ, Makowski L. The inflammation highway: metabolism accelerates inflammatory traffic in obesity. Immunol Rev (2012) 249(1):218-38. doi:10.1111/j.1600-065X.2012.01151.x

64. Thompson RW, Pesce JT, Ramalingam T, Wilson MS, White S, Cheever AW, et al. Cationic amino acid transporter-2 regulates immunity by modulating arginase activity. PLoS Pathog (2008) 4(3):e1000023. doi:10.1371/journal.ppat.1000023

65. Qualls JE, Subramanian C, Rafi W, Smith AM, Balouzian L, DeFreitas AA, et al. Sustained generation of nitric oxide and control of mycobacterial infection requires argininosuccinate synthase 1. Cell Host Microbe (2012) 12(3):313-23. doi:10.1016/j.chom.2012.07.012

66. Das P, Lahiri A, Lahiri A, Chakravortty D. Modulation of the arginase pathway in the context of microbial pathogenesis: a metabolic enzyme moonlighting as an immune modulator. PLoS Pathog (2010) 6(6):e1000899. doi:10.1371/ journal.ppat.1000899

67. Bronte V, Zanovello P. Regulation of immune responses by L-arginine metabolism. Nat Rev Immunol (2005) 5(8):641-54. doi:10.1038/nril668

68. Gordon S. Alternative activation of macrophages. Nat Rev Immunol (2003) 3(1):23-35. doi:10.1038/nri978

69. Liu G, Bi Y, Shen B, Yang H, Zhang Y, Wang X, et al. SIRT1 limits the function and fate of myeloid-derived suppressor cells in tumors by orchestrating HIF-1alpha-dependent glycolysis. Cancer Res (2014) 74(3):727-37. doi:10.1158/0008-5472.can-13-2584

70. Hsu PP, Sabatini DM. Cancer cell metabolism: warburg and beyond. Cell (2008) 134(5):703-7. doi:10.1016/j.cell.2008.08.021

71. Cairns RA, Harris IS, Mak TW. Regulation of cancer cell metabolism. Nat Rev Cancer (2011) 11(2):85-95. doi:10.1038/nrc2981

72. Amelio I, Cutruzzola F, Antonov A, Agostini M, Melino G. Serine and glycine metabolism in cancer. Trends Biochem Sci (2014) 39(4):191-8. doi:10.1016/j. tibs.2014.02.004

73. Estrela JM, Ortega A, Obrador E. Glutathione in cancer biology and therapy. Crit Rev Clin Lab Sci (2006) 43(2):143-81. doi:10.1080/10408360500523878
74. Trachootham D, Alexandre J, Huang P. Targeting cancer cells by ROS-mediated mechanisms: a radical therapeutic approach? Nat Rev Drug Discov (2009) 8(7):579-91. doi:10.1038/nrd2803

75. Estrella V, Chen T, Lloyd M, Wojtkowiak J, Cornnell HH, Ibrahim-Hashim A, et al. Acidity generated by the tumor microenvironment drives local invasion. Cancer Res (2013) 73(5):1524-35. doi:10.1158/0008-5472.can-12-2796

76. Annibaldi A, Widmann C. Glucose metabolism in cancer cells. Curr Opin Clin Nutr Metab Care (2010) 13(4):466-70. doi:10.1097/MCO.0b013e32833a5577

77. Liang J, Mills GB. AMPK: a contextual oncogene or tumor suppressor? Cancer Res (2013) 73(10):2929-35. doi:10.1158/0008-5472.can-12-3876

78. Sabatini DM. mTOR and cancer: insights into a complex relationship. Nat Rev Cancer (2006) 6(9):729-34. doi:10.1038/nrc1974

79. Reiling JH, Sabatini DM. Stress and mTORture signaling. Oncogene (2006) 25(48):6373-83. doi:10.1038/sj.onc.1209889

80. Vousden KH, Ryan KM. p53 and metabolism. Nat Rev Cancer (2009) 9(10):691-700. doi:10.1038/nrc2715

81. Altman BJ, Rathmell JC. Metabolic stress in autophagy and cell death pathways. Cold Spring Harb Perspect Biol (2012) 4(9):a008763. doi:10.1101/cshperspect. a008763

82. Lob S, Konigsrainer A, Rammensee HG, Opelz G, Terness P. Inhibitors of indoleamine-2,3-dioxygenase for cancer therapy: can we see the wood for the trees? Nat Rev Cancer (2009) 9(6):445-52. doi:10.1038/nrc2639

83. Munn DH, Mellor AL. Indoleamine 2,3-dioxygenase and tumor-induced tolerance. J Clin Invest (2007) 117(5):1147-54. doi:10.1172/jci31178

84. Pilotte L, Larrieu P, Stroobant V, Colau D, Dolusic E, Frederick R, et al. Reversal of tumoral immune resistance by inhibition of tryptophan 2,3dioxygenase. Proc Natl Acad Sci U S A (2012) 109(7):2497-502. doi:10.1073/ pnas.1113873109

85. Adams S, Braidy N, Bessede A, Brew BJ, Grant R, Teo C, et al. The kynurenine pathway in brain tumor pathogenesis. Cancer Res (2012) 72(22):5649-57. doi:10.1158/0008-5472.can-12-0549

86. Veldhoen M, Hirota K, Christensen J, O'Garra A, Stockinger B. Natural agonists for aryl hydrocarbon receptor in culture medium are essential for optimal differentiation of Th17 T cells. J Exp Med (2009) 206(1):43-9. doi:10.1084/jem.20081438

87. Nguyen NT, Hanieh H, Nakahama T, Kishimoto T. The roles of aryl hydrocarbon receptor in immune responses. Int Immunol (2013) 25(6):335-43. doi:10.1093/intimm/dxt011

88. Nguyen NT, Kimura A, Nakahama T, Chinen I, Masuda K, Nohara K, et al. Aryl hydrocarbon receptor negatively regulates dendritic cell immunogenicity via a kynurenine-dependent mechanism. Proc Natl Acad Sci U S A (2010) 107(46):19961-6. doi:10.1073/pnas.1014465107

89. Mezrich JD, Fechner JH, Zhang X, Johnson BP, Burlingham WJ, Bradfield CA. An interaction between kynurenine and the aryl hydrocarbon receptor can generate regulatory T cells. J Immunol (2010) 185(6):3190-8. doi:10.4049/ jimmunol.0903670

90. Opitz CA, Litzenburger UM, Sahm F, Ott M, Tritschler I, Trump S, et al. An endogenous tumour-promoting ligand of the human aryl hydrocarbon receptor. Nature (2011) 478(7368):197-203. doi:10.1038/nature10491

91. D'Autreaux B, Toledano MB. ROS as signalling molecules: mechanisms that generate specificity in ROS homeostasis. Nat Rev Mol Cell Biol (2007) 8(10):813-24. doi:10.1038/nrm2256

92. Ray PD, Huang BW, Tsuji Y. Reactive oxygen species (ROS) homeostasis and redox regulation in cellular signaling. Cell Signal (2012) 24(5):981-90. doi:10.1016/j.cellsig.2012.01.008

93. Srivastava MK, Sinha P, Clements VK, Rodriguez P, Ostrand-Rosenberg S Myeloid-derived suppressor cells inhibit T-cell activation by depleting cystine and cysteine. Cancer Res (2010) 70(1):68-77. doi:10.1158/0008-5472.can-092587

94. Wink DA, Vodovotz Y, Laval J, Laval F, Dewhirst MW, Mitchell JB. The multifaceted roles of nitric oxide in cancer. Carcinogenesis (1998) 19(5):711-21. doi:10.1093/carcin/19.5.711

95. Fukumura D, Kashiwagi S, Jain RK. The role of nitric oxide in tumour progression. Nat Rev Cancer (2006) 6(7):521-34. doi:10.1038/nrc1910

96. Choudhari SK, Chaudhary M, Bagde S, Gadbail AR, Joshi V. Nitric oxide and cancer: a review. World J Surg Oncol (2013) 11:118. doi:10.1186/1477-781911-118 
97. Feun L, You M, Wu CJ, Kuo MT, Wangpaichitr M, Spector S, et al. Arginine deprivation as a targeted therapy for cancer. Curr Pharm Des (2008) 14(11):1049-57. doi:10.2174/138161208784246199

98. Lind DS. Arginine and cancer. J Nutr (2004) 134(10 Suppl):2837S-41S.

99. Rodriguez PC, Quiceno DG, Ochoa AC. L-arginine availability regulates Tlymphocyte cell-cycle progression. Blood (2007) 109(4):1568-73. doi:10.1182/ blood-2006-06-031856

100. Lamas B, Vergnaud-Gauduchon J, Goncalves-Mendes N, Perche O, Rossary A, Vasson MP, et al. Altered functions of natural killer cells in response to L-Arginine availability. Cell Immunol (2012) 280(2):182-90. doi:10.1016/j. cellimm.2012.11.018

101. Ambs S, Merriam WG, Ogunfusika MO, Bennett WP, Ishibe N, Hussain SP, et al. p53 and vascular endothelial growth factor regulate tumor growth of NOS2-expressing human carcinoma cells. Nat Med (1998) 4(12):1371-6. doi:10.1038/3957

102. Rajnakova A, Moochhala S, Goh PM, Ngoi S. Expression of nitric oxide synthase, cyclooxygenase, and p53 in different stages of human gastric cancer. Cancer Lett (2001) 172(2):177-85. doi:10.1016/S0304-3835(01)00645-0

103. Bonavida B, Baritaki S. Dual role of NO donors in the reversal of tumor cell resistance and EMT: downregulation of the NF-kappaB/Snail/YY1/RKIP circuitry. Nitric Oxide (2011) 24(1):1-7. doi:10.1016/j.niox.2010.10.001

104. Wongvaranon P, Pongrakhananon V, Chunhacha P, Chanvorachote P. Acquired resistance to chemotherapy in lung cancer cells mediated by prolonged nitric oxide exposure. Anticancer Res (2013) 33(12):5433-44.

105. Wachsberger P, Burd R, Dicker AP. Tumor response to ionizing radiation combined with antiangiogenesis or vascular targeting agents: exploring mechanisms of interaction. Clin Cancer Res (2003) 9(6):1957-71.

106. Fischer K, Hoffmann P, Voelkl S, Meidenbauer N, Ammer J, Edinger M, et al. Inhibitory effect of tumor cell-derived lactic acid on human $\mathrm{T}$ cells. Blood (2007) 109(9):3812-9. doi:10.1182/blood-2006-07-035972

107. Dietl K, Renner K, Dettmer K, Timischl B, Eberhart K, Dorn C, et al. Lactic acid and acidification inhibit TNF secretion and glycolysis of human monocytes. J Immunol (2010) 184(3):1200-9. doi:10.4049/jimmunol.0902584

108. Samuvel DJ, Sundararaj KP, Nareika A, Lopes-Virella MF, Huang Y. Lactate boosts TLR4 signaling and NF-kappaB pathway-mediated gene transcription in macrophages via monocarboxylate transporters and MD-2 up-regulation. J Immunol (2009) 182(4):2476-84. doi:10.4049/jimmunol.0802059

109. Reshkin SJ, Cardone RA, Harguindey S. Na+-H+ exchanger, pH regulation and cancer. Recent Pat Anticancer Drug Discov (2013) 8(1):85-99. doi:10.2174/ 1574892811308010085

110. Kleinewietfeld M, Manzel A, Titze J, Kvakan H, Yosef N, Linker RA, et al. Sodium chloride drives autoimmune disease by the induction of pathogenic TH17 cells. Nature (2013) 496(7446):518-22. doi:10.1038/nature11868
111. Wu C, Yosef N, Thalhamer T, Zhu C, Xiao S, Kishi Y, et al. Induction of pathogenic TH17 cells by inducible salt-sensing kinase SGK1. Nature (2013) 496(7446):513-7. doi:10.1038/nature11984

112. Gladden LB. Lactate metabolism: a new paradigm for the third millennium. J Physiol (2004) 558(Pt 1):5-30. doi:10.1113/jphysiol.2003.058701

113. Philp A, Macdonald AL, Watt PW. Lactate - a signal coordinating cell and systemic function. J Exp Biol (2005) 208(Pt 24):4561-75. doi:10.1242/jeb.01961

114. Dhup S, Dadhich RK, Porporato PE, Sonveaux P. Multiple biological activities of lactic acid in cancer: influences on tumor growth, angiogenesis and metastasis. Curr Pharm Des (2012) 18(10):1319-30. doi:10.2174/138161212799504902

115. Roth S, Droge W. Regulation of interleukin 2 production, interleukin 2 mRNA expression and intracellular glutathione levels in ex vivo derived Tymphocytes by lactate. Eur J Immunol (1991) 21(8):1933-7. doi:10.1002/eji.1830210823

116. Roth S, Gmunder H, Droge W. Regulation of intracellular glutathione levels and lymphocyte functions by lactate. Cell Immunol (1991) 136(1):95-104. doi:10.1016/0008-8749(91)90384-N

117. Husain Z, Huang Y, Seth P, Sukhatme VP. Tumor-derived lactate modifies antitumor immune response: effect on myeloid-derived suppressor cells and NK cells. J Immunol (2013) 191(3):1486-95. doi:10.4049/jimmunol.1202702

118. Shime H, Yabu M, Akazawa T, Kodama K, Matsumoto M, Seya T, et al. Tumorsecreted lactic acid promotes IL-23/IL-17 proinflammatory pathway. JImmunol (2008) 180(11):7175-83. doi:10.4049/jimmunol.180.11.7175

119. Crowther M, Brown NJ, Bishop ET, Lewis CE. Microenvironmental influence on macrophage regulation of angiogenesis in wounds and malignant tumors. J Leukoc Biol (2001) 70(4):478-90.

Conflict of Interest Statement: The authors declare that the research was conducted in the absence of any commercial or financial relationships that could be construed as a potential conflict of interest.

Received: 11 June 2014; accepted: 12 July 2014; published online: 28 July 2014.

Citation: Wang T, Liu $G$ and Wang $R$ (2014) The intercellular metabolic interplay between tumor and immune cells. Front. Immunol. 5:358. doi: 10.3389/fimmu.2014.00358

This article was submitted to Inflammation, a section of the journal Frontiers in Immunology.

Copyright (c) 2014 Wang, Liu and Wang. This is an open-access article distributed under the terms of the Creative Commons Attribution License (CC BY). The use, distribution or reproduction in other forums is permitted, provided the original author(s) or licensor are credited and that the original publication in this journal is cited, in accordance with accepted academic practice. No use, distribution or reproduction is permitted which does not comply with these terms. 